J'ALL JOALL (JOURNAL OF APPIIID LINGUISTICS AND LI'TERA'TURE)

Vol. 7 No. 1, February 2022

ISSN (print): 2502-7816; ISSN (online): 2503-524X

Available online at https:/ / ejournal.unib.ac.id/index.php/joall/article/view/16594

http://doi.org/10.33369/joall.v7i1.16594

\title{
Promoting English movie as a means of enhancing EFL learners' cultural competence
}

\author{
${ }^{1}$ Dwi Suny Wardhany
}

\author{
${ }^{1}$ Faculty of Teacher Training and Education, Universitas Ahmad Dahlan, INDONESIA \\ ${ }^{1}$ JalanPramuka No. 42 Sidikan 55161, Yogyakarta
}

\begin{tabular}{|c|c|}
\hline ARTICLE INFO & \multirow{6}{*}{$\begin{array}{l}\text { Very few studies discussing the use of English movies for the } \\
\text { enhancement of EFL learners' cultural competence in } \\
\text { Indonesia. This study aims to describe the results of analyzing } \\
\text { relevant research articles regarding the use of English } \\
\text { movie/film for enhancing the cultural competence of EFL } \\
\text { learners. This study was descriptive-qualitative. The data were } \\
\text { taken from } 7 \text { (seven) research articles related to the study } \\
\text { objective. In collecting the data (the research articles), the } \\
\text { researcher conducted literature research or library research. It } \\
\text { was carried out by searching, identifying, and selecting the } \\
\text { research articles related to the study objective from electronic } \\
\text { databases. Then, the data were analyzed by using qualitative } \\
\text { data analysis which consists of data reduction, data display, } \\
\text { and drawing the conclusion. The results showed that the seven } \\
\text { research articles reported the enhancement of EFL learners' } \\
\text { cultural competence in terms of students' attitude, knowledge, } \\
\text { skills and cultural awareness. In addition, } 3 \text { research articles } \\
\text { reported the enhancement of students' language skills i.e., } \\
\text { speaking, vocabulary, reading, and listening through learning } \\
\text { activities done during and after watching and analyzing } \\
\text { English movies. Therefore, it is suggested that English teachers } \\
\text { pay attention to the culture teaching in ELT. English teachers } \\
\text { can select appropriate English movie/film in the classroom as } \\
\text { a means to enhance students' cultural competence and to } \\
\text { enhance students' language skills. }\end{array}$} \\
\hline $\begin{array}{l}\text { Article history: } \\
\text { Received: June 30, } 2021 \\
\text { Revised: Feb 04, } 2022 \\
\text { Accepted: Feb 13, } 2022\end{array}$ & \\
\hline $\begin{array}{l}\text { Keywords: } \\
\text { Cultural competence } \\
\text { English movie } \\
\text { English learning } \\
\text { EFL }\end{array}$ & \\
\hline $\begin{array}{l}\text { Conflict of interest: } \\
\text { None }\end{array}$ & \\
\hline $\begin{array}{l}\text { Funding information: } \\
\text { None }\end{array}$ & \\
\hline $\begin{array}{l}\text { Correspondence: } \\
\text { Dwi Suny Wardhany, Faculty of } \\
\text { Teacher Training and Education, } \\
\text { Universitas Ahmad Dahlan, } \\
\text { INDONESIA } \\
\text { dwi.wardhany@gmail.com }\end{array}$ & \\
\hline
\end{tabular}

This is an open access article under the CC BY-SA 4.0 international license.

How to cite (APA Style):

Wardhany, D.S. (2022). Promoting English movie as a means of enhancing EFL learners' cultural competence. JOALL (Journal of Applied Linguistics and Literature), 7(1), 186-201.

https://doi.org/10.33369/joall.v7i1.16594

The Regulation of the Minister of Education and Culture Number 37 of 2018 concerning core competencies and basic competencies of lessons in the 2013 curriculum stipulates the regulations regarding English subject for secondary education. There are four competencies that should be achieved by students in secondary education. Two of these competencies are knowledge and skills. 
In the core competence of knowledge, it is stated that students are expected to be able to understand knowledge about science, technology, art, and culture. In the basic knowledge competence it is stated that students are expected to be able to identify social functions, text structures, and linguistic elements of texts according to the context of their use. While, in the core competence of skills, students are expected to have skills related to language and communication skills. In short, students are expected to understand and master the linguistic knowledge and the cultural knowledge in order to use the language to communicate appropriately and effectively in all situations.

Alluri (2018) stated that 'there is a saying that every language has its own culture'. It can be conceived that there is a need to know and understand the culture of the language being learned so that the purpose to be able to use the language for communication successfully in accordance with the social context can be achieved. As explained by Alptekin (2002) that appropriate use of the language necessitates attention to the concept of social context which refers to the culture-specific context such as the norms, values, beliefs, and behavior patterns of a culture. This is in line with the government regulations mentioned above that in the context of English foreign language learning, having both linguistic knowledge and cultural knowledge is essential and complementary to successfully mastering the target language in achieving meaningful and effective communication. Students cannot be taken into consideration of mastering a foreign language until they understand the cultural contexts in which the target language is spoken (NSFLEP, 1996) as cited in Frank (2013).

Both the knowledge of grammar rules and rules of language used appropriately to a given context are part of communicative competence. It was first introduced by Hymes (1972). Several researchers have contributed to the advancement of communicative competence. Byram (1997) expanded on the concept of communicative competence as intercultural communicative competence. According to Byram and Fleming (1998) as cited in Yalcin (2013), two important communicative competences necessitate the development of cultural awareness.

Lynch \& Hanson (1998) defined cultural competence as 'the ability to think, feel, and act in ways that acknowledge, respect, and build upon ethnic, socio-cultural, and linguistic diversity'. In other words, it is the ability to interact and to respond appropriately as well as to respect and to cherish people from different cultures. Tran and Seepho (2014) proposed three elements of cultural competence namely attitudes toward cultural differences, knowledge of different cultural practices and worldviews, and skills to interact effectively with people of different cultures. In addition, Feng and Xue (2018) argued four components of cultural competence which seemed complementing the previous cultural competence elements. The four 
components are: (a) awareness of one's own cultural worldview, (b) attitude towards cultural differences, (c) knowledge of different cultural practices and worldviews, and (d) cross-cultural skills.

Since the acquisition of cultural knowledge is imperative in English language learning, teachers need to include teaching culture to provide students with cultural competence. In spite of the current status of English as a Global or International language in which culture teaching not only focus on the target culture but also to the diverse cultures, teachers still need to provide students with some familiarity with the culture associated with target language. English teachers need to introduce English culture to students so that the students have a comprehension of the target culture that would help them in using English for communication in accordance with the social context. Without knowing and understanding the culture of the target language, misunderstanding and errors could happen. In fact, English teachers face some obstacles in teaching culture in English foreign language classroom. Some of the problems include limited cultural knowledge, limited material and resources, and support from the curriculum, limited time to prepare the lesson, and no training acquired by the teachers from their educational background related to the teaching method of teaching culture in ELT (Mumu, 2017).

Teachers can use English movie in teaching culture for the development of students' cultural competence. Yalcin (2013) stated that movie films chosen appropriately which have rich content of different aspects of culture can be an appropriate tool to enhance understanding of cultural differences. Purba (2011) explained that film offers students an opportunity to witness behaviors that are not obvious in texts. Film encloses the look, feel, and rhythm of a culture. Likewise, Zhao (2011) asserted that the themes, conversations and actions in movies mirror the habits, beliefs, and customs of the culture, which can serve as good introduction about the various cultural characteristics in English-speaking countries. Furthermore, Mirvan (2013) stated that 'films offer a visual context aids which help students understand and improve their reading skills'. In short, films or movies can be utilized as the learning medium to teach and learn both the language and the culture.

In exploiting English movie/film for culture teaching, a teacher should select appropriate movie/film by seeing the movie firsthand to determine if it is appropriate for the desired lesson (Roell, 2010). After watching, the teacher can give students an assignment to analyze the movie they already watched. Furthermore, Frank (2013) proposed cultural observation when watching English movie. Teacher can ask students to describe the behaviors they see in the movie and to discuss differences and similarities between their own culture and the culture they are observing. By doing these activities, students get exposures to the authentic speech of the language and to the 
authentic various communicative situations. It can help students get better on their language skills and also their cultural knowledge.

A previous study conducted by Yugai and Kovaleva (2004) was to reveal the utilization of film discourse as an approach in teaching English as second language to the students of Foreign Language Institutes and Universities. The findings revealed that the use of authentic film discourse (movies) is an effective approach to develop both linguistic and socio-cultural competences. Another study conducted by Nur (2014) was aimed to find out students' attitude towards the use of films in increasing students' cultural awareness in Cross Cultural Understanding (CCU) class. The result showed that the students had positive attitude toward the use of films in CCU class. Moreover, the use of films increased students' cultural awareness because they get information from the movie, they can compare their culture with other cultures, and it can prevent them from culture shock.

However, the search of literature regarding the use of movie in ELT for cultural competence revealed that there are many studies have been done on discussing the use of English movie as medium to increase students' language skills such as speaking, listening, reading and writing. Meanwhile, only little attention has been given to the use of movie in enhancing cultural competence of EFL students in Indonesia. Therefore, it is still needed to be further explored and promoted. In view of this shortcoming, this study proposes to answer the following research question: What are the results of analyzing relevant research articles regarding the use of English movie/film for cultural competence of EFL learners?

\section{METHOD}

Associated with the objective of the study, the design of this study was descriptive-qualitative. According to Sandelowski (2000), in descriptive qualitative, researchers attempting to describe an experience or event, choose what they will describe by highlighting specific aspects of it, and begin to transform that experience or event. In this study, I attempted to describe the results of analyzing relevant research articles regarding the use of English movie for cultural competence of EFL learners. I select the findings of the research articles to be described and highlighted the important points related to the objective of present study.

\section{Data collection}

The data were taken from research articles related to the study objective. The search of the research articles was performed in Google Scholar, ResearchGate, and ScienceDirect using the keywords "movies for enhancing cultural competence in EFL learning" and "movies for cultural competence in EFL learning in Indonesia". The search on the electronic database resulted in 
45 studies and decreased to 7 research articles after the selection process. The 45 studies were identified and 17 studies were excluded due to not in the context of ELT. Then, 28 studies were chosen to be screened by titles and abstracts to meet the criteria of examining the use of movies for the development of cultural competence in EFL learning. 13 studies were excluded because when the studies were further explored, the discussions did not focus on the enhancement of cultural competence through using movies/films and one study did not use English language. Thus, 15 studies were selected for the review. The full texts of those studies then were examined to meet the inclusion criteria. But later, 8 studies were excluded due to conference paper (3), and thesis or dissertations (5).

After the selection process, 7 research articles were obtained in this study as follows:

1. Effects of Integrating Movie-Based Mobile Learning Instruction for Enhancing Thai University Students' Speaking Skills and Intercultural Communicative Competence (Chaya and Inpin, 2020).

2. Cross-Cultural Competence: Examining EFL Students' Views of U.S. Holiday Culture Through Film (Lee, 2017)

3. A Diary Study of University EFL Learners' Intercultural Learning through Foreign Films (Chao, 2013).

4. How Chinese College Students Make Sense of Foreign Films and TV Series: Implications for the Development of Intercultural Communicative Competence in ELT (Yang and Fleming, 2013).

5. Students' Intercultural Development through Language Learning in Vietnamese Tertiary Education: A Case Study on the Use of Film as an Innovative Approach (Truong and Tran, 2014).

6. Use of Foreign Films in Cultivating Intercultural Communicative Competence in ELT-A Case Study (Yue, 2019).

7. Increasing Students' Intercultural Awareness Using Film as the Media in the EFL Classroom (Kartikasari, Retnaningdyah and Mustofa, 2019).

\section{Instruments}

Creswell (2014) stated that in qualitative research, the researcher is the key instrument who collects data themselves through examining documents, observing behavior, or interviewing participants. They may use an instrument for collecting data, but the researchers are the ones who actually collect the information. In this study, the researcher herself collected the data in the form of research articles to be examined.

In collecting the data (the research articles), I conducted literature research or library research. According to Sari and Asmendri (2020), Library research is carried out by collecting information and data with the help of various materials available in libraries or sources from the internet related to 
the problem to be solved. This activity is carried out systematically to collect, process, and conclude data using certain methods / techniques to find answers on the problems faced. In this study, I sought and collected the research articles related to the research topic from the internet (electronic databases). When selecting relevant articles for this research, the inclusion and exclusion criteria were applied.

The inclusion criteria:

1. Studies exploring about the use of movies for the enhancement of cultural competence in EFL learning.

2. Publication years between 2011 to 2021 .

3. Studies related to English language learning and teaching.

4. Studies published in the English language.

5. Studies published in academic journals or peer-reviewed journals. The exclusion criteria:

1. Undergraduate theses, graduate theses, doctoral theses, books, conference papers.

The selection process is presented in the figure 1 below:
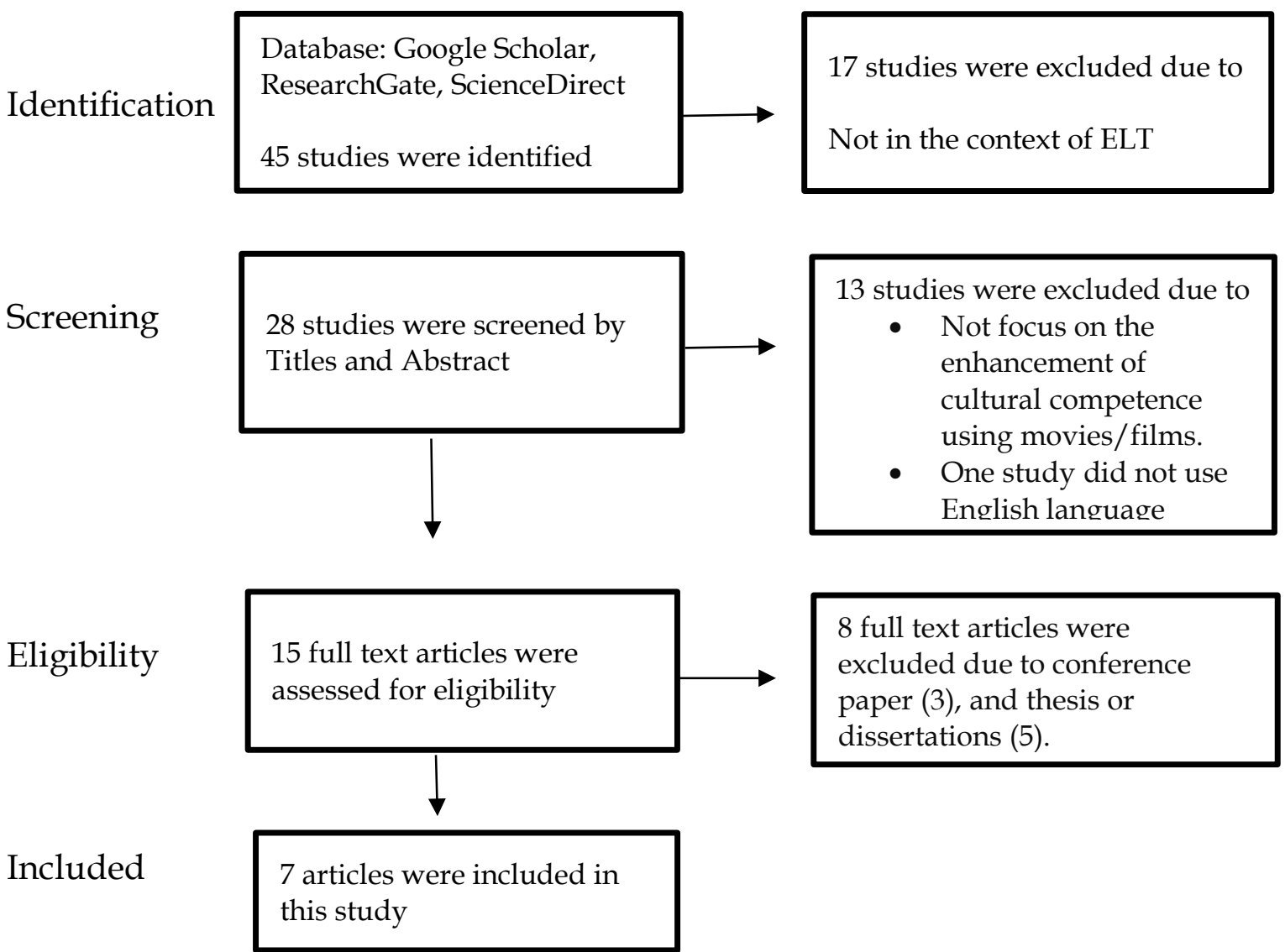

Figure 1: The selection process adapted from Hashemi and Kew (2021) 


\section{Data analysis procedures}

In analyzing the data, I employed qualitative data analysis proposed by Miles and Huberman (1994). It consists of data reduction, data display, and drawing the conclusion. In the reduction, I selected the research articles related to the research topic by applying the inclusion and exclusion criteria. The data obtained from the search in the electronic databases began with 45 studies and decreased to 7 studies after the selection process. The full texts of those 7 research articles then were analyzed. I wrote the important points regarding the methods of the articles and summarized the findings of the studies. Then, in displaying the data, the data that has been reduced were displayed to provide an understanding of the data. To display the data that has been reduced, I chose to display them in the table. I classified the data into three categories to be displayed in the table. The categories were research title, data sources and research design, and research findings. Then, the reduced data related to the three categories based on the results of analyzing the 7 research articles were displayed in the table. After data reduction and data display were carried out, then conclusion can be drawn from the data studied. In drawing the conclusion, I focused on the research findings of the seven research articles regarding the use of English movies/films for the cultural competence of EFL learners. I interpreted the findings of the articles, connected them to the theory of the elements of cultural competence mentioned in the introduction in order to get the answer for the research questions.

\section{FINDINGS}

Based on data collection through the literature research or library research, there were 7 research articles found by the researcher related to the research topic. The results of analyzing the research articles related to the use of English movie/film for cultural competence of EFL learners are presented as follows:

Table 1. The Results of Analyzing the Research Articles

\begin{tabular}{|c|c|c|c|}
\hline No & Research Title & $\begin{array}{l}\text { Data Sources and } \\
\text { Research Design }\end{array}$ & Research Findings \\
\hline 1 & $\begin{array}{l}\text { Effects of Integrating } \\
\text { Movie-Based Mobile } \\
\text { Learning Instruction for } \\
\text { Enhancing Thai } \\
\text { University Students' } \\
\text { Speaking Skills and } \\
\text { Intercultural } \\
\text { Communicative } \\
\text { Competence }\end{array}$ & $\begin{array}{l}\text { The participants were } \\
\text { two groups of first-year } \\
\text { undergraduate } \\
\text { students. } \\
\text { This research was a } \\
\text { quasi-experimental } \\
\text { study with a non- } \\
\text { equivalent pretest- } \\
\text { posttest control group } \\
\text { design. }\end{array}$ & $\begin{array}{l}\text { The findings indicated that the } \\
\text { implementation of the MBML } \\
\text { (Movie-Based Mobile } \\
\text { Learning) instruction } \\
\text { enhanced Thai university } \\
\text { students' English-speaking } \\
\text { skills and Intercultural } \\
\text { Communicative Competence. }\end{array}$ \\
\hline
\end{tabular}




\begin{tabular}{|c|c|c|c|}
\hline No & Research Title & $\begin{array}{l}\text { Data Sources and } \\
\text { Research Design }\end{array}$ & Research Findings \\
\hline & & $\begin{array}{l}\text { Data sources: speaking } \\
\text { test, the intercultural } \\
\text { communicative } \\
\text { competence } \\
\text { questionnaire, } \\
\text { Technology Acceptance } \\
\text { Model (TAM) } \\
\text { questionnaire, and the } \\
\text { interview. }\end{array}$ & $\begin{array}{l}\text { According to the statistical } \\
\text { results, students in the } \\
\text { experimental group had } \\
\text { improvement on their ICC } \\
\text { (Intercultural Communicative } \\
\text { Competence) in all three } \\
\text { elements, including attitudes } \\
\text { toward diverse cultures, } \\
\text { intercultural knowledge, and } \\
\text { skills of interpreting and } \\
\text { relating to other cultures. } \\
\text { Moreover, based on the } \\
\text { speaking posttest, the } \\
\text { experimental group had } \\
\text { improved their speaking skills } \\
\text { after getting MBML } \\
\text { instruction. }\end{array}$ \\
\hline 2 & $\begin{array}{l}\text { Cross-Cultural } \\
\text { Competence: } \\
\text { Examining EFL } \\
\text { Students' Views of U.S. } \\
\text { Holiday Culture } \\
\text { Through Film }\end{array}$ & $\begin{array}{l}\text { The participants were } 45 \\
\text { Korean university } \\
\text { students majoring in } \\
\text { English. } \\
\text { This research was } \\
\text { qualitative with a case } \\
\text { study design. } \\
\text { Data sources: a } \\
\text { completed worksheet, } \\
\text { class discussions and } \\
\text { class observation. }\end{array}$ & $\begin{array}{l}\text { After the implementation of } \\
\text { watching and analyzing an } \\
\text { American Christmas movie, } \\
\text { students gained more } \\
\text { insights related to the U.S. } \\
\text { Christmas culture which } \\
\text { covering (a) the importance } \\
\text { of Christmas parties, (b) gift } \\
\text { giving, compassion and } \\
\text { socioeconomic status, (c) } \\
\text { relationships with family, } \\
\text { friends and neighbors, (d) } \\
\text { home and neighborhood } \\
\text { decorations, and (e) holiday } \\
\text { stress. Moreover, from the } \\
\text { linguistic aspect, students } \\
\text { developed their vocabulary } \\
\text { and expressions related to } \\
\text { U.S. Christmas culture which } \\
\text { they might not have learned } \\
\text { in language classes that focus } \\
\text { on general conversation } \\
\text { topics. }\end{array}$ \\
\hline 3 & $\begin{array}{l}\text { A Diary Study of } \\
\text { University EFL } \\
\text { Learners' Intercultural } \\
\text { Learning Through } \\
\text { Foreign Films }\end{array}$ & $\begin{array}{l}\text { This research used } \\
\text { qualitative method. Data } \\
\text { sources were learners' } \\
\text { diaries. } \\
\text { The participants were } 52 \\
\text { Taiwan university } \\
\text { students majoring in } \\
\text { English. }\end{array}$ & $\begin{array}{l}\text { The results indicated that } \\
\text { film instruction has positive } \\
\text { impact on the development } \\
\text { of Intercultural competence. } \\
\text { A great number of students } \\
\text { showed evident progress in } \\
\text { the development of } \\
\text { intercultural motivations, }\end{array}$ \\
\hline
\end{tabular}




\begin{tabular}{|c|c|c|c|}
\hline No & Research Title & $\begin{array}{l}\text { Data Sources and } \\
\text { Research Design }\end{array}$ & Research Findings \\
\hline & & $\begin{array}{l}\text { The activities include: } \\
\text { Pre-viewing. } \\
\text { During-viewing. } \\
\text { Post-viewing. } \\
\text { Advanced post-viewing. }\end{array}$ & $\begin{array}{l}\text { attitudes, knowledge and } \\
\text { awareness. In addition, some } \\
\text { students claimed to have } \\
\text { improved their English skills } \\
\text { i.e., reading and listening as } \\
\text { a result of being exposed to } \\
\text { films with English speech or } \\
\text { subtitles. }\end{array}$ \\
\hline 4 & $\begin{array}{l}\text { How Chinese College } \\
\text { Students Make Sense of } \\
\text { Foreign Films and TV } \\
\text { Series: Implications for } \\
\text { the Development of } \\
\text { Intercultural } \\
\text { Communicative } \\
\text { Competence in ELT }\end{array}$ & $\begin{array}{l}\text { This study was qualitative } \\
\text { with semi-structured } \\
\text { interviews as data } \\
\text { collection technique. } \\
\text { The participants were } 21 \\
\text { Chinese undergraduate } \\
\text { college students. } \\
\text { Semi-structured } \\
\text { interviews were } \\
\text { conducted based on short } \\
\text { films clips chosen and } \\
\text { viewed by the students. } \\
\text { After watching, students } \\
\text { were asked questions to } \\
\text { find out how they } \\
\text { responded to the clips. }\end{array}$ & $\begin{array}{l}\text { The findings showed that } \\
\text { there are five categories in } \\
\text { the sense-making of foreign } \\
\text { films: (1) comprehending } \\
\text { the plot, (2) comparing: } \\
\text { identifying differences, (3) } \\
\text { comparing: identifying } \\
\text { similarities, (4) re- } \\
\text { contextualizing, and (5) } \\
\text { perceiving as realistic. } \\
\text { These sense-making } \\
\text { activities help student } \\
\text { develop their intercultural } \\
\text { communicative competence } \\
\text { in terms of their skills of } \\
\text { interpreting/relating. }\end{array}$ \\
\hline 5 & $\begin{array}{l}\text { Students' Intercultural } \\
\text { Development through } \\
\text { Language Learning in } \\
\text { Vietnamese Tertiary } \\
\text { Education: A Case } \\
\text { Study on the Use of } \\
\text { Film as an Innovative } \\
\text { Approach }\end{array}$ & $\begin{array}{l}\text { The participants were } 16 \\
\text { Vietnamese tertiary } \\
\text { students of English in } \\
\text { Central Vietnam. } \\
\text { This study was a case study. } \\
\text { Data were collected through } \\
\text { in-depth interviews with } \\
\text { students, student reflective } \\
\text { journals, and video } \\
\text { recorded of class } \\
\text { observation }\end{array}$ & $\begin{array}{l}\text { The results indicated that } \\
\text { students' understanding } \\
\text { of other cultures } \\
\text { enhanced. Their } \\
\text { interpretations of the } \\
\text { scenes evoked a range of } \\
\text { emotions, including } \\
\text { confusion, surprise and } \\
\text { acceptance. There were } \\
\text { five themes emerged } \\
\text { related to student } \\
\text { intercultural learning: (1) } \\
\text { enhancing students' } \\
\text { knowledge about the } \\
\text { difference of culture, (2) } \\
\text { making cross-cultural } \\
\text { comparisons through } \\
\text { teacher guidance, (3) } \\
\text { defying cultural } \\
\text { stereotypes, (4) involving } \\
\text { students in authentic } \\
\text { learning through the story } \\
\text { and the scenes, and (5) } \\
\text { fostering intercultural }\end{array}$ \\
\hline
\end{tabular}




\begin{tabular}{|c|c|c|c|}
\hline No & Research Title & $\begin{array}{l}\text { Data Sources and } \\
\text { Research Design }\end{array}$ & Research Findings \\
\hline & & & $\begin{array}{l}\text { competence through } \\
\text { intercultural language } \\
\text { learning in an integrated } \\
\text { mode. }\end{array}$ \\
\hline 6 & $\begin{array}{l}\text { Use of Foreign Films in } \\
\text { Cultivating } \\
\text { Intercultural } \\
\text { Communicative } \\
\text { Competence in ELT-A } \\
\text { Case Study }\end{array}$ & $\begin{array}{l}\text { The participants were } 30 \\
\text { non-English Major Chinese } \\
\text { undergraduate students } \\
\text { who are required to take } \\
\text { 'College English'. } \\
\text { This study was qualitative } \\
\text { with a case study. } \\
\text { Data sources were students' } \\
\text { study blogs, quizzes and } \\
\text { interviews. }\end{array}$ & $\begin{array}{l}\text { The results showed that } \\
\text { watching foreign films } \\
\text { and reflecting on } \\
\text { students' interpretation of } \\
\text { foreign films is beneficial } \\
\text { in developing students' } \\
\text { ICC in terms of their } \\
\text { attitude, knowledge, skills } \\
\text { of interpreting and } \\
\text { relating, skills of } \\
\text { discovery and interaction, } \\
\text { and critical awareness. } \\
\text { Students showed positive } \\
\text { attitude such as they } \\
\text { demonstrated their } \\
\text { interest to watch films } \\
\text { and they showed } \\
\text { curiosity to know other } \\
\text { cultures. Furthermore, } \\
\text { after watching, students' } \\
\text { knowledge in } \\
\text { understanding the plot } \\
\text { enhanced, they are also } \\
\text { able to interpret and } \\
\text { compare another culture } \\
\text { to their own, they are able } \\
\text { to re-contextualize the } \\
\text { story and they showed } \\
\text { strong critical awareness } \\
\text { commenting on the film. }\end{array}$ \\
\hline 7 & $\begin{array}{l}\text { Increasing Students' } \\
\text { Intercultural } \\
\text { Awareness Using Film } \\
\text { as the Media in the EFL } \\
\text { classroom }\end{array}$ & $\begin{array}{l}\text { This research was } \\
\text { qualitative with a case } \\
\text { study design. The } \\
\text { participants were } 36 \\
\text { students of tenth grade high } \\
\text { school in Surabaya, } \\
\text { Indonesia. } \\
\text { Data were collected through } \\
\text { observation sheets, field } \\
\text { notes, and students' journal } \\
\text { writing. }\end{array}$ & $\begin{array}{l}\text { The findings showed that } \\
\text { the teacher used certain } \\
\text { technique which was } \\
\text { helpful to develop } \\
\text { students' intercultural } \\
\text { awareness (ICA). This } \\
\text { technique is called QAR } \\
\text { taxonomy which consists } \\
\text { of } 4 \text { categories: "Right } \\
\text { There", "Think and } \\
\text { Search", "Own Your } \\
\text { Own", and "Author and } \\
\text { You". In addition, there } \\
\text { were twenty-one aspects }\end{array}$ \\
\hline
\end{tabular}




\begin{tabular}{lll}
\hline No $\quad$ Research Title & $\begin{array}{l}\text { Data Sources and } \\
\text { Research Design }\end{array}$ & \multicolumn{1}{c}{ Research Findings } \\
\hline & $\begin{array}{l}\text { of Intercultural awareness } \\
\text { students perceived from } \\
\text { the film. One of the } \\
\text { aspects is 'respect for } \\
\text { others' becoming the key } \\
\text { of all aspects of ICA. }\end{array}$ \\
\hline
\end{tabular}

Based on the description of the findings above, it can be concluded that the use of movies/films in English language learning enhanced students' cultural competence in terms of students' knowledge of different cultures, students' attitude towards different cultures, students' cultural skills in interacting and understanding as well as students' cultural awareness. In addition, 3 research articles reported that the findings of the studies indicated the enhancement of students' language skills i.e., speaking, vocabulary, reading, and listening obtained throughout and after watching and analyzing movies/films in English language learning.

\section{DISCUSSION}

The findings showed that the implementation of watching and analyzing English movies/films in English language teaching and learning enhanced students' cultural competence. The results of analyzing seven research articles reported the enhancement of EFL learners' cultural competence in terms of students' knowledge of different cultures, students' attitude towards different cultures, students' cultural skills in interacting and understanding as well as students' cultural awareness. These findings are in accordance with Feng and Xue (2018) who argued four components of cultural competence, namely: (a) awareness of one's own cultural worldview, (b) attitude towards cultural differences, (c) knowledge of different cultural practices and worldviews, and (d) cross-cultural skills. These findings also support the finding of previous study which confirmed the use of films increased students' cultural awareness (Nur, 2014).

In terms of students' knowledge of different cultures, the second and the fifth research articles reported the development of students' knowledge of different cultures. The second research article (Lee, 2017) reported that after watching and analyzing American Christmas movie, students' knowledge of U.S. Christmas culture increased. They acquired more insights about U.S. Christmas culture which students had inaccurate or incomplete perception before related to: (a) the importance of Christmas parties, (b) gift giving, compassion and socioeconomic status, (c) relationships with family, friends and neighbors, (d) home and neighborhood decorations, and (e) holiday stress. Then, the fifth research article (Truong and Tran, 2014) reported that the intercultural learning using American movie enhanced students' 
understanding about other cultures such as values, communication styles, and beliefs. In terms of students' attitude towards different cultures, the sixth research article (Yue, 2019) reported that students showed positive attitude. They demonstrated their interest to watch foreign films and they showed curiosity such as they are open to other cultures. In terms of students' cultural skills in interacting and understanding, the fourth research article (Yang and Fleming, 2013) reported that the sense-making activities after watching foreign films and TV series help student develop their skills of understanding the cultural themes in foreign films and interpreting/relating, for instance students can identify differences and similarities of other cultures and connect them with their own cultures. Then, the sixth research article (Yue, 2019) reported that students develop their ICC (intercultural communicative competence) in terms of skills of discovery and interaction such as they are able to re-contextualize the story and some students make the recontextualizing by putting themselves into the main character's shoes. Furthermore, in terms of students' cultural awareness, the third and the last research articles reported the development of cultural awareness. For instances, the third research articles (Chao, 2013) reported that many participants recognized that discriminating against other cultures was wrong, they acknowledged the significance of cultivating a global open-minded attitude, and they were proud of their culture. Then, finding of the last article (Kartikasari, Retnaningdyah, and Mustofa, 2019) showed there were twenty one aspects of intercultural awareness perceived by students from film and one of the aspects, namely 'respect to others' becoming the key of all aspects of ICA (intercultural awareness).

The findings also showed that 3 research articles reported the enhancement of students' language skills i.e., speaking, vocabulary, reading, and listening gained during and after watching and analyzing English movies. The first research article (Chaya and Inpin, 2020) reported that based on the speaking posttest, students in the experimental group had improved their speaking skills after getting MBML (Movie-Based Mobile Learning) instruction. The second research article (Lee, 2017) reported that watching and analyzing American Christmas movie developed students' vocabulary and expressions related to U.S. Christmas culture such as 'honey baked ham', 'caramel cream pie', 'baby's first Christmas', 'Frosty the Snowman', 'Scrooge', etc. Then, the third research article (Chao, 2013) reported that some students claimed to have improved their English skills i.e., reading and listening as a result of being exposed to films with English speech or subtitles. These findings are in line with Roell (2010) who states that movie or film is a rich resource for language learning. The use of authentic language combined with drama that stimulates thinking expands cultural competence and enhances English learning. The results also support the findings of previous study 
which asserted that the use of films is an effective approach to develop both linguistic and socio-cultural competences (Yugai and Kovaleva, 2004). This indicated that English movie/film instruction in EFL learning is not only beneficial for cultural learning but also for language learning.

\section{CONCLUSION}

Developing cultural competence is essential in EFL learning to help students successfully master the target language in order to communicate effectively and appropriately with people from different cultures. In fact, English teachers face some obstacles in teaching culture in English foreign language classroom. One of the problems is no training acquired by the teachers from their educational background related to the teaching method of teaching culture in ELT. Films or movies can be utilized as the learning medium to support teaching culture in ELT. The findings showed that the results of analyzing seven research articles reported the enhancement of EFL learners' cultural competence in terms of students' knowledge of different cultures, students' attitude towards different cultures, students' cultural skills in interacting and understanding as well as students' cultural awareness. In addition, 3 research articles reported that the findings of the studies indicated the enhancement of students' language skills i.e., speaking, vocabulary, reading, and listening through learning activities done during and after watching and analyzing English movies. The studies reported that the enhancement of students' language skills was obtained through the application of speaking posttest, class discussions, and English speech or subtitles in movie. The findings indicated that the use of English movies/films in English language teaching and learning is beneficial to EFL learners for their development of cultural and linguistic competence. Therefore, it is suggested that English teachers pay attention to the culture teaching in ELT. English teachers can select appropriate English movie/film in the classroom as means to enhance students' cultural competence and to enhance students' language skills.

\section{ACKNOWLEDGMENTS}

The author would like to express her gratitude to the journal editor as well as the anonymous reviewers for their feedback on previous versions of this work.

\section{REFERENCES}

Alluri, P. (2018). Enhancing English Language Teaching through Films in General Foundation Programs. Arab World English Journal, AWEJ Proce(1), 146-154. https://doi.org/10.24093/awej/mec1.11

Alptekin, C. (2002). Towards intercultural communicative competence in 
ELT. ELT Journal, 56(1), 57-64. https://doi.org/10.1093/elt/56.1.57 Byram, M. (1997). Teaching and Accessing Intercultural Communicative Competence. London: Multilingual Matters.

Chao, T. (2013). A diary study of university EFL learners ' intercultural learning through foreign films. Language, Culture and Curriculum, 26(3), 247-265. https:/ / doi.org/10.1080/07908318.2013.833936

Chaya, P., \& Inpin, B. (2020). Effects of Integrating Movie-Based Mobile Learning Instruction for Enhancing Thai University Students' Speaking Skills and Intercultural Communicative Competence. English Language Teaching, 13(7), 27-45. https:/ / doi.org/10.5539/elt.v13n7p27

Creswell, J. W. (2014). Research Design: Qualitative, Quantitative, and Mixed Methods Approaches (4th Editio). United States of America: SAGE Publications, Inc.

FENG, W.-N., \& XUE, W. (2018). The Effects of British and American Films and TV Series on Improving Intercultural Communication Competence. 2nd International Conference on Modern Education and Information Technology (MEIT 2018), (meit), 118-121. https://doi.org/10.12783/dtssehs/meit2018/27636

Frank, J. (2013). Raising Cultural Awareness in the English Language Classroom. English Teaching Forum, 51(4), 2-11. Retrieved from http:/ / https/ / eric.ed.gov/?id=EJ1020809 on April 15, 2021

Hashemi, A., \& Kew, S. N. (2021). The Barriers to the Use of ICT in English Language Teaching: A Systematic Literature Review. Journal of Information and Communication Technologies, 3(1), 77-88.

Hymes, D. H. (1972). On Communicative Competence. England: Penguin Books.

Kartikasari, Y. D. N., Retnaningdyah, P., \& Mustofa, A. (2019). Increasing Students' Intercultural Awareness Using Film as the Media in the EFL Classroom. International Journal for Educational and Vocational Studies, 1(7), 681-690.

Lee, A. R. (2017). Cross-Cultural Competence: Examining EFL Students' Views of U.S. Holiday Culture Through Film. STEM Journal, 18(3), 1-27. https://doi.org/10.16875/stem.2017.18.3.1

Lynch, Eleanor W., Hanson, M. J. (1998). Developing Cross-Cultural Competence: A Guide for Working With Children and Their Families (2nd Editio). Baltimore: Brookes.

Miles, M. B., \& Huberman, A. M. (1994). Qualitative Data Analysis. In Sage Publications (Second Edi). Thousand Oaks, CA: SAGE Publications, Inc. Mirvan, X. (2013). The Advantages of Using Films to Enhance Student's Reading Skills in the EFL Classroom. Journal of Education and Practice, 4(13), 62-67.

Mumu, E. L. (2017). An Exploration of Teachers' Beliefs on the Integration of 
Culture in Teaching English as a Foreign Language in Junior High Schools in Minahasa/Indonesia. Murdoch University, Western Australia.

Nur, S. (2014). Increasing Students' Cultural Awareness by Using Film in Teaching Cross Cultural Understanding. Paper Presented at the Proceedings of the 61tst TEFLIN International Conference, UNS Solo, 371373.

Permendikbud. (2018). Permendikbud RI Nomor 37 tahun 2018 tentang Perubahan atas Peraturan Menteri Pendidikan dan Kebudayaan Nomor 24 tahun 2016 tentang Kompetensi Inti dan Kompetensi Dasar Pelajaran pada Kurikulum 2013 pada Pendidikan Dasar dan Pendidikan Menengah. JDIH Kemendikbud, 2025, 1-527.

Purba, H. (2011). The Importance of Including Culture in EFL Teaching. JET (Journal of English Teaching), 1(1), 44-56. https://doi.org/10.33541/jet.v1i1.51

Roell, C. (2010). Intercultural Training with Films. English Teaching Forum, 48(2), 2-15. Retrieved from http:/ / files.eric.ed.gov/fulltext/EJ914887.pdf

Sandelowski, M. (2000). Focus on Research Methods: Whatever Happened to Qualitative Description? Research in Nursing and Health, 23, 334-340. https://doi.org/10.1002/1098-240x(200008)23:4<334::aid-nur9>3.0.co;2$\mathrm{g}$

Sari, M., \& Asmendri, A. (2020). Penelitian Kepustakaan (Library Research) dalam Penelitian Pendidikan IPA. Natural Science: Jurnal Penelitian Bidang IPA Dan Pendidikan IPA, 6(1), 41-53. Retrieved from https://ejournal.uinib.ac.id/jurnal/index.php/naturalscience/article/ view/1555/1159

Tran, T. Q., \& Seepho, S. (2014). An Empirical Study on Teachers' Perceptions and their Incorporating Cultural Competence in English Language Teaching. Proceedings of the 2014 International Conference on English Language Teaching (ICELT), (24-25 October 2014), 517-531.

Truong, L. B., \& Tran, L. T. (2014). Students' intercultural development through language learning in Vietnamese tertiary education: a case study on the use of film as an innovative approach. Language and Intercultural Communication, 14(2), 207-225. https:/ / doi.org/10.1080/14708477.2013.849717

Yalcin, N. (2013). Using Movies in Language Classrooms as Means of Understanding Cultural Diversity. Epiphany, 6(1), 260-271. https://doi.org/10.21533/epiphany.v6i1.65

Yang, L. H., \& Fleming, M. (2013). How Chinese college students make sense of foreign films and TV series: implications for the development of intercultural communicative competence in ELT. The Language Learning Journal, 41(3), 297-310. https:/ / doi.org/10.1080/09571736.2013.836347 
Yue, J. (2019). Use of Foreign Films in Cultivating Intercultural Communicative Competence in ELT - A Case Study. Theory and Practice in Language Studies, 9(2), 198-203.

Yugai, T., \& Kovaleva, M. (2014). Film Discourse in Training Socio-Cultural Competence. LEARNING LANGUAGES - BUILDING COMMUNITIES PAC@9th FEELTA International Conference on Language Teaching, 254-257. Vladivostok.

Zhao, B. (2011). How to Enhance Culture Teaching in English Language Classes. Theory and Practice in Language Studies, 1(7), 847-850. https://doi.org/10.4304/tpls.1.7.847-850

\section{THE AUTHOR}

Dwi Suny Wardhany is a graduate student of English Language Education of Universitas Ahmad Dahlan, Yogyakarta, Indonesia who has completed her master thesis. She earned her Bachelor's degree in English Literature from Universitas Teknologi Yogyakarta. Her research interests include Culture in ELT, Literature for Language Teaching and Learning, and Technology Enhanced Language Learning. 